\title{
Impact of Straw Burning Practices on Economics of Sugarcane in South Gujarat Region, India
}

\author{
Narendra Singh $^{1^{*}}$, V.M. Thumar ${ }^{2}$, A.K. Leua ${ }^{3}$ and D.J. Chaudhari ${ }^{1}$ \\ ${ }^{1}$ Department of Agricultural Economics, ACHF, NAU, Navsari, Gujarat, India \\ ${ }^{2}$ Directorate of Research, NAU, Navsari, Gujarat, India \\ ${ }^{3}$ ASPEE Agribusiness Management Institute (AABMI), NAU, Navsari, Gujarat, India \\ *Corresponding author
}

\section{A B S T R A C T}

Sugarcane is the major crop grown in South Gujarat region contributing to major share o farmer's income and state economy with highest area and production in Navsari and Surat

Keywords

Sugarcane, Straw burning, Practices, Ratoon, Return

Article Info

Accepted:

04 August 2018

Available Online:

10 September 2018 districts. Since past several years, farmers are burning sugarcane straw at the time of harvesting the crop which is serious problem causing environmental damage and public health issues. Keeping in view this problem it is essential to study the economic aspect of straw burning practices in South Gujarat region. For this purpose the present investigation was undertaken to study the comparative costs and return of sugarcane non-straw burning and straw burning practices. The results of study revealed that per hectare net return of sugarcane planted and ratoon crop for non-straw burning practice was found Rs. 268393.84 and Rs. 222207.56 whereas it was Rs. 225386.84 and Rs. 181687.70 for straw burning practices respectively. The return per rupee was also recognized less in straw burning practices as compare to non-straw burning practices. Traditionally sugarcane farmers burn their crop before harvesting of the crop to reduce labour and transportation cost. The burning practices of the farmers reduce their income by deduction of Rs.150 per tonnes and weight loss of 10-12 tonnes per hectare.

\section{Introduction}

Biomass burning is a global phenomenon and can be an important contributor to poor air quality worldwide (Yang et al., 2008). Biomass burning includes forest fires, prescribed burning of savannas, and crop residue burning in fields (Jain et al., 2014). Change in composition of the atmosphere may have a direct or indirect effect on the radiation balance of earth affecting its climate and contributing to global climate change (Streets et al., 2003; Koppmann et al., 2005). The burning practice for sugarcane residues varies worldwide. In many countries, such as Brazil, Guatemala, Mexico, and Costa Rica, preharvest burning is a common practice. In the United States and the Philippines, sugarcane fields are burned either before or after harvest, but in India, most of the sugarcane residues are usually burned in the field only after harvest due to lack of proper composting techniques (França et al., 2012). The major 
sugarcane producing areas of world have recently adopted the practice of mechanical harvesting (Cardoso et al., 2013; Unica, 2015). In this system, dry leaves, tips and green leaves are cut off and thrown on the soil surface forming a straw that acts as mulch over soil surface (Oliveira et al., 2002 and Aquino et al., 2016). More than 300 million $\mathrm{Mg}$ of straw is produced per year worldwide (Unica, 2015).

Costa et al., (2014) observed that the total removal of straw significantly reduced sugarcane production, as compared with keeping straw residue over field, for either short or longer time period. Ball-Coelho et al., (1993) stated that in low rainfall or rainfall is irregular straw as ground cover has contributed to the increase in sugarcane productivity. Sugarcane straw coat protects the soil in all segments of the soil erosion because it absorbs the kinetic energy of the rain drops, decreases the speed of runoff and hinders disarticulation of the particles (Braunbeck and Magalhaes, 2010). Consequently, safeguarding of stubble on the surface is a importance management practices for sustainability of the sugarcane production system. They also emphasized that the straw reduces soil water loss of approximately $70 \%$, and reduction in the soil temperature and increase of organic matter, favoring the largest structure of soil microbiota and also increasing the crop root system (Aquino et al., 2016).

India is the second largest producer and the largest consumer of sugar in the world. India contributes about 15 percent of world sugar production and has annual production of about 25-28 million tonnes in recent past. Presently, about 5 million hectares of land is under sugarcane cultivation with annual production of about 356 million tonnes and average yield of around 71 tonnes per hectare in TE 201516. Sugarcane crop is the major crop grown in South Gujarat region of the state. It contributes 89.89 and 90.01 per cent of the total production and area of the state, respectively. Navsari and Surat districts contribute 70.00 and 72.00 per cent of total area and total production of South Gujarat, respectively. Sugarcane crop being a major crop of South Gujarat region contributing to the economy of the state, since past several years, farmers are burning sugarcane straw at the time of harvesting the crop. Normally, the sugarcane crop is harvested manually and chaff is used for feed of animals as well as biomass. But for saving time, money and labour farmers are going to adopt chaff burn practices before harvesting the sugarcane crop. The sugarcane straw and residue are burnt in the fields for their easy harvesting and cleaning the field. Burning of sugarcane straw affects badly the sugar recovery from the cane as well as damage the soil in terms of loss of organic matter, soil nutrients, and loss of useful flora \& fauna and fire accidents. It is very important to study the economic aspects of sugarcane straw burning, which practice is prevailing in the region. The study estimates the economic loss to the farmers with the objectives; a) estimate the cost of cultivation of sugarcane under straw burning and nonburning practices, b) estimate the economic loss in straw burning practices c) identify the reasons for adoption of straw burning practices

\section{Materials and Methods}

Major two sugarcane growing districts i.e. Surat and Navsari of South Gujarat region of the state were selected for the study. One taluka from each selected district and two villages from each taluka were selected purposively on the basis of area under sugarcane. From each selected village 15 farmers each following burning and nonburning practices were selected for the study. Thus, total of 120 farmers were selected. The required data was collected by survey method 
during the year 2016-17 and 2017-18 through well-structured schedule.

\section{Analytical tools}

Cost of cultivation and returns from sugarcane cultivation was estimated using standardized C.A.C.P cost concepts. Gross returns were calculated at the price to which the sugarcane crop was sold to the sugar factory. Returns were calculated by subtracting costs as $A_{1}, A_{2}$, $\mathrm{B}_{1}, \mathrm{~B}_{2}, \mathrm{C}_{1}, \mathrm{C}_{2}$, and cost $\mathrm{C}_{3}$ from gross returns.

\section{Results and Discussion}

\section{Cost of cultivation for sugarcane non-straw burning practices}

The component wise various costs incurred in the cultivation of sugarcane planted and ratoon crop for straw burning and non-burning practices are given in Table 1. In case of sugarcane planted, the overall cost of cultivation of sugarcane planted was Rs. 184990.16. Of the total cost of cultivation, 24.74 per cent (Rs. 45767.80/ha) expenditure was incurred as operational cost, human labour constituted the most important component of operational cost with its share of more than 22 per cent. The material cost accounted 48.26 per cent (Rs. 89280.68/ha), among the material cost items 18.16 per cent expenses incurred on planting material while fertilizer, irrigation manures and plant protection accounted 11.64, 8.97, 2.83 and 0.71 per cent, respectively. The share of rental value of own land accounted 11.95 per cent (Rs. 22104.00/ ha) and the remaining was accounted by land revenue, depreciation on implements, interest on working capital and interest on fixed capital of the total cost of cultivation.

Total cost of cultivation of sugarcane ratoon crop was Rs. 132779.94 which consists of 27.49 per cent of the operational cost and
42.31 per cent of the material cost. In the operational cost, more than 27 per cent expenses incurred on human labour alone and on machinery it was about 0.38 per cent of the total cost. Within the material cost expenditure on fertilizer, irrigation, manure and plant protection chemicals was $14.77,11.79,4.03$ and 0.80 per cent, respectively. Rental value of own land was 15.03 per cent (Rs. 19955/ha) of total cost of cultivation and the remaining was accounted by land revenue, depreciation on implements, interest on working capital and interest on fixed capital.

\section{Cost of cultivation for sugarcane straw burning practices}

The table 1 indicates that on an average, per hectare cost of cultivation of sugarcane planted under straw burning practices was Rs. 175365.16. Out of total cost of cultivation, share of operational cost is 21.11 percent while material costs accounted for 50.91 percent and share of other costs was 18.89 percent. Among the total cost of cultivation, human labour, planting material, fertilizers, irrigation and manures are the major cost items accounting 18.68, 19.16, 12.28, 9.47 and 2.98 percent, respectively. Rental value of own land accounted 12.60 per cent (Rs. $22104.00 /$ ha) of total cost of cultivation and the remaining was accounted by land revenue, depreciation on implements, interest on working capital and interest on fixed capital.

Cost of cultivation of sugarcane ratoon was Rs.124621.20. The share of operational cost accounted for 23.67 per cent (Rs. 29495.00/ha) of the total cost, and again human labour constituted the most important component of operational cost with share of more than 23 per cent of the total cost, the material cost accounted for 45.08 per cent (Rs. $56177.00 /$ ha), rental value of own land accounted for a share of 16.01 per cent (Rs. 19955.00/ha) of total cost of sugarcane ratoon 
and the balance was accounted by land revenue, interest on fixed capital, depreciation on implements, interest on working capital and interest on fixed capital etc.

\section{Cost concept}

\section{Sugarcane non straw burning practices}

To estimate the cost groups, the cost concept as adopted in the scheme of cost of cultivation on principal crops operated by Directorate of Economics and Statistics, Government of India were used. These cost concepts are cost $A_{1}$, cost $A_{2}$, cost $B_{1}$, cost $B_{2}$, cost $C_{1}$, cost $C_{2}$ and cost $C_{3}$. Table 2 shows that average per hectare total cost of cultivation (Cost C3) of sugarcane planted was Rs 184990. Cost $A_{1}$, $\operatorname{cost} A_{2}$, cost $B_{1}$, cost $B_{2}$, cost $C_{1}$ and cost $C_{2}$ were Rs 140397, Rs 140397, Rs 141064, Rs 163168, Rs 146069 and Rs 168173 per hectare, respectively. The average total cost $\left(\right.$ Cost $\left.\mathrm{C}_{3}\right)$ per hectare in cultivation of sugarcane ratoon was $\mathrm{Rs} 132780$. Cost $\mathrm{A}_{1}$, $\operatorname{cost} A_{2}$, cost $B_{1}$, cost $B_{2}$, cost $C_{1}$ and $\operatorname{cost} C_{2}$ were Rs 94374, Rs 94374, Rs 94919, Rs 114874, Rs 1100754 and Rs 120709 per hectare, respectively.

\section{Sugarcane straw burning practices}

Table 2 shows that average per hectare total cost of cultivation (Cost C3) of sugarcane planted was Rs 175365 . Cost $A_{1}$, cost $A_{2}$, cost $\mathrm{B}_{1}$, cost $\mathrm{B}_{2}$, cost $\mathrm{C}_{1}$ and $\operatorname{cost} \mathrm{C}_{2}$ were Rs 131647, Rs 131647, Rs 132314, Rs 154418, Rs 137319 and Rs 159423 per hectare, respectively. The average total cost $\left(\operatorname{Cost} \mathrm{C}_{3}\right)$ per hectare in cultivation of sugarcane ratoon was Rs 124621. Cost $A_{1}$, cost $A_{2}$, cost $B_{1}$, cost $\mathrm{B}_{2}$, cost $\mathrm{C}_{1}$ and cost $\mathrm{C}_{2}$ were Rs 86957, Rs 86957, Rs 87502, Rs 107457, Rs 93337 and Rs 113292 per hectare, respectively. The study results are in conformity with Singh et al., (2008) and Kant et al., (2015).

\section{Returns from cultivation of sugarcane crop}

The area allocation, decision and choice of a crop to be grown on an area to the large extent, depends mainly on returns from the crop. The per hectare returns from cultivation of sugarcane has been presented in Table 3.

\section{Sugarcane non straw burning practices}

Table 3 shows the per hectare yield of sugarcane planted and ratoon was found to be 1080 and 875.00. The prices of sugarcane received by the farmers of the sugarcane planted and ratoon was Rs. 419.80 and Rs. 405.70/qtl. Gross return was calculated by the addition of value of main product and value of by-product. The gross return per hectare was Rs. 453384.00 and Rs. 354987.50 in the sugarcane planted and ratoon crop respectively. Per hectare net return of sugarcane planted and ratoon crop was found Rs. 268393.84 and Rs. 222207.56. The profit margin per hectare obtained for sugarcane planted and ratoon crop with non-burning practices was 2.70 and 2.94. The table also explains that the overall per quintal cost of production of sugarcane planted and ratoon crop was Rs. 155.72 and Rs. 137.95 per quintal. The results are in conformity with Kumar et al., 2014)

\section{Sugarcane straw burning practices}

The per hectare yield of sugarcane planted and ratoon under straw burning practices was found to be 990.00 and 784.00 . The prices received by the farmers of the sugarcane planted and ratoon was Rs. 404.80 and Rs. 390.70/qtl. The gross return per hectare was Rs. 400752.00 and Rs. 306308.80 in the sugarcane planted and ratoon crop respectively. Net reurn per hectare of sugarcane planted and ratoon crop was found to be Rs. 225386.84 and Rs.181687.60, respectively. 
Table.1 Cost of cultivation of sugarcane panted and ratoon for straw burning and Non-burning practices

\begin{tabular}{|c|c|c|c|c|c|c|c|c|}
\hline \multirow{3}{*}{\begin{tabular}{|c|} 
Cost of cultivation \\
Variable cost
\end{tabular}} & \multicolumn{4}{|c|}{ Sugarcane non straw burning practices } & \multicolumn{4}{|c|}{ Sugarcane straw burning practices } \\
\hline & \multicolumn{2}{|c|}{ Sugarcane Planted } & \multicolumn{2}{|c|}{ Sugarcane Ratoon } & \multicolumn{2}{|c|}{ Sugarcane Planted } & \multicolumn{2}{|c|}{ Sugarcane Ratoon } \\
\hline & $\begin{array}{l}\text { Value } \\
\text { (Rs./ha) }\end{array}$ & $\%$ & $\begin{array}{l}\text { Value } \\
\text { (Rs./ha) }\end{array}$ & $\%$ & $\begin{array}{l}\text { Value } \\
\text { (Rs./ha) }\end{array}$ & $\%$ & $\begin{array}{l}\text { Value } \\
\text { (Rs./ha) }\end{array}$ & $\%$ \\
\hline \multicolumn{9}{|l|}{ (A) Operational cost } \\
\hline Family labour & 5004.80 & 2.71 & 5835.00 & 4.39 & 5004.80 & 2.85 & 5835.00 & 4.68 \\
\hline Hired labour & 36513.00 & 19.74 & 30156.00 & 22.71 & 27763.00 & 15.83 & 23156.00 & 18.58 \\
\hline Bullock/Machine labour & 4250.00 & 2.30 & 504.00 & 0.38 & 4250.00 & 2.42 & 504.00 & 0.40 \\
\hline Sub total (A) & 45767.80 & 24.74 & 36495.00 & 27.49 & 37017.80 & 21.11 & 29495.00 & 23.67 \\
\hline (B) Material cost & & 0.00 & & 0.00 & & 0.00 & & 0.00 \\
\hline Seed & 33603.00 & 18.16 & 0.00 & 0.00 & 33603.00 & 19.16 & 0.00 & 0.00 \\
\hline Manures and cakes & 5229.68 & 2.83 & 5350.00 & 4.03 & 5229.68 & 2.98 & 5350.00 & 4.29 \\
\hline Irrigation charges & 16602.00 & 8.97 & 15652.00 & 11.79 & 16602.00 & 9.47 & 15652.00 & 12.56 \\
\hline Fertilizer & 21536.00 & 11.64 & 19614.00 & 14.77 & 21536.00 & 12.28 & 19614.00 & 15.74 \\
\hline Insecticides/pesticides & 1310.00 & 0.71 & 1061.00 & 0.80 & 1310.00 & 0.75 & 1061.00 & 0.85 \\
\hline Miscellaneous & 11000.00 & 5.95 & 14500.00 & 10.92 & 11000.00 & 6.27 & 14500.00 & 11.64 \\
\hline Sub total (B) & 89280.68 & 48.26 & 56177.00 & 42.31 & 89280.68 & 50.91 & 56177.00 & 45.08 \\
\hline $\begin{array}{l}\text { Total of variable cost } \\
(\mathrm{A}+\mathrm{B})\end{array}$ & 135048.48 & 73.00 & 92672.00 & 69.79 & 126298.48 & 72.02 & 85672.00 & 68.75 \\
\hline \multicolumn{9}{|l|}{ (C) Other cost } \\
\hline $\begin{array}{l}\text { Interest on working } \\
\text { capital }\end{array}$ & 9453.39 & 5.11 & 6487.04 & 4.89 & 9453.39 & 5.39 & 6070.00 & 4.87 \\
\hline Depreciation & 900.00 & 0.49 & 1050.00 & 0.79 & 900.00 & 0.51 & 1050.00 & 0.84 \\
\hline $\begin{array}{l}\text { Interest on own fixed } \\
\text { capital }\end{array}$ & 667.00 & 0.36 & 545.00 & 0.41 & 667.00 & 0.38 & 545.00 & 0.44 \\
\hline Rental value of own land & 22104.00 & 11.95 & 19955.00 & 15.03 & 22104.00 & 12.60 & 19955.00 & 16.01 \\
\hline Sub total $(\mathrm{C})$ & 33124.39 & 17.91 & 28037.04 & 21.12 & 33124.39 & 18.89 & 27620.00 & 22.16 \\
\hline Cost $C_{2} *$ total $(A+B+C)$ & 168172.87 & 90.91 & 120709.04 & 90.91 & 159422.87 & 90.91 & 113292.00 & 90.91 \\
\hline $\begin{array}{l}10 \% \text { of } \mathrm{C}_{2} * \text { for } \\
\text { managerial work }\end{array}$ & 16817.29 & 9.09 & 12070.90 & 9.09 & 15942.29 & 9.09 & 11329.20 & 9.09 \\
\hline Cost $C_{3=}\left(C_{2}{ }^{*}+C_{2} * 10 \%\right)$ & 184990.16 & 100.00 & 132779.94 & 100.00 & 175365.16 & 100.00 & 124621.20 & 100.00 \\
\hline
\end{tabular}

Table.2 Cost concept in cost of cultivation of sugarcane planted and ratoon crop for straw burning and non-burning practices

\begin{tabular}{|c|c|c|c|c|c|c|c|c|}
\hline \multirow{3}{*}{$\begin{array}{l}\text { Particulars } \\
\text { Cost of } \\
\text { cultivation }\end{array}$} & \multicolumn{4}{|c|}{ Sugarcane non straw burning practices } & \multicolumn{4}{|c|}{ Sugarcane straw burning practices } \\
\hline & \multicolumn{2}{|c|}{ Sugarcane Planted } & \multicolumn{2}{|c|}{ Sugarcane Ratoon } & \multicolumn{2}{|c|}{ Sugarcane Planted } & \multicolumn{2}{|c|}{ Sugarcane Ratoon } \\
\hline & $\begin{array}{l}\text { Value } \\
\text { (Rs./ha) }\end{array}$ & $\%$ & $\begin{array}{l}\text { Value } \\
\text { (Rs./ha) }\end{array}$ & $\%$ & $\begin{array}{l}\text { Value } \\
\text { (Rs./ha) }\end{array}$ & $\%$ & $\begin{array}{l}\text { Value } \\
\text { (Rs./ha) }\end{array}$ & $\%$ \\
\hline Cost-A1 & 140397 & 75.89 & 94374 & 71.08 & 131647 & 75.07 & 86957 & 69.78 \\
\hline Cost-A2 & 140397 & 75.89 & 94374 & 71.08 & 131647 & 75.07 & 86957 & 69.78 \\
\hline Cost-B1 & 141064 & 76.25 & 94919 & 71.49 & 132314 & 75.45 & 87502 & 70.21 \\
\hline Cost-B2 & 163168 & 88.20 & 114874 & 86.51 & 154418 & 88.06 & 107457 & 86.23 \\
\hline Cost-C1 & 146069 & 78.96 & 100754 & 75.88 & 137319 & 78.30 & 93337 & 74.90 \\
\hline Cost-C2 & 168173 & 90.91 & 120709 & 90.91 & 159423 & 90.91 & 113292 & 90.91 \\
\hline Cost-C3 & 184990 & 100.00 & 132780 & 100.00 & 175365 & 100.00 & 124621 & 100.00 \\
\hline
\end{tabular}


Table.3 Returns from sugarcane planted and ratoon for straw burning and non-burning practices

\begin{tabular}{|c|c|c|c|c|}
\hline \multirow[t]{2}{*}{ Particulars } & \multicolumn{2}{|c|}{ Sugarcane non straw burning practices } & \multicolumn{2}{|c|}{ Sugarcane straw burning practices } \\
\hline & Sugarcane Planted & Sugarcane Ratoon & Sugarcane Planted & Sugarcane Ratoon \\
\hline Yield (q/ha) & 1080.00 & 875.00 & 990.00 & 784.00 \\
\hline Prices (Rs./q) & 419.80 & 405.70 & 404.80 & 390.70 \\
\hline Return (Rs./ ha) & 453384.00 & 354987.50 & 400752.00 & 306308.80 \\
\hline Gross return (Rs./ha) & 453384.00 & 354987.50 & 400752.00 & 306308.80 \\
\hline Net return (Rs./ha) & 268393.84 & 222207.56 & 225386.84 & 181687.60 \\
\hline $\begin{array}{l}\text { Difference in Gross } \\
\text { return (if Burn) }\end{array}$ & & & 52632.00 & 48678.70 \\
\hline \multicolumn{5}{|c|}{ Return over various costs (Rs./ha) } \\
\hline Cost $A_{1}$ & 312986.93 & 260613.46 & 269104.93 & 219351.80 \\
\hline Cost $A_{2}$ & 312986.93 & 260613.46 & 269104.93 & 219351.80 \\
\hline Cost $B_{1}$ & 312319.93 & 358464.96 & 268437.93 & 313250.00 \\
\hline Cost $\mathrm{B}_{2}$ & 290215.93 & 240113.46 & 246333.93 & 198851.80 \\
\hline Cost $C_{1}$ & 307315.13 & 352629.96 & 263433.13 & 307415.00 \\
\hline Cost $\mathbf{C 2}$ & 285211.13 & 234278.46 & 241329.13 & 193016.80 \\
\hline Cost $\mathrm{C}_{3}$ & 268393.84 & 222207.56 & 225386.84 & 181687.60 \\
\hline $\begin{array}{l}\text { Cost of sugarcane } \\
\text { production (Rs./q) }\end{array}$ & 155.72 & 137.95 & 161.03 & 144.51 \\
\hline Returns per rupee & 2.70 & 2.94 & 2.51 & 2.70 \\
\hline $\begin{array}{l}\text { \% loss over non straw } \\
\text { burning practices }\end{array}$ & - & - & 11.61 & 13.71 \\
\hline
\end{tabular}

Table.4 Impact of straw burning practices in sugarcane

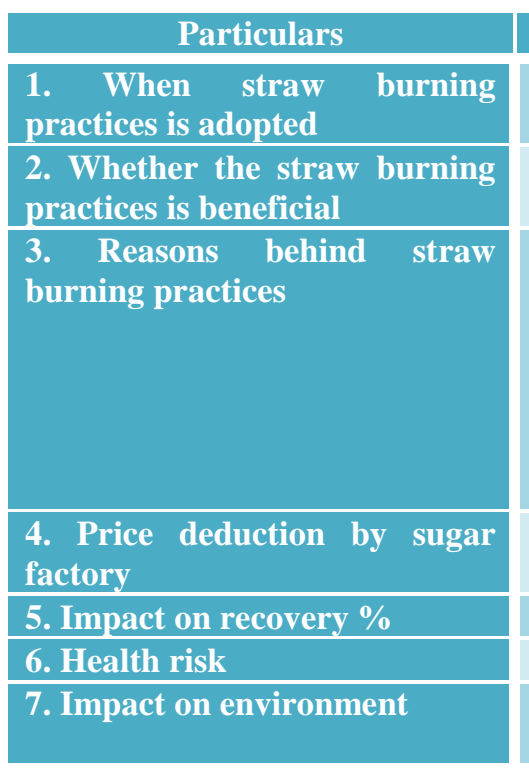

Farmers response

Traditionally framers adopted burning practices.

Farmers response is Yes but economically loss. Yield weight loss is up to 10-12 tonnes /ha.

Sugarcane field burning is carried out before harvesting of the crop to make the process easier and require less labour. In burning process, the the field is set fire to and the leaves are burned off of the stalks. About $80 \%$ of the trash including straw, the tops and green and dry leaves are burned off. These components constitute about $25 \%$ of the entire sugarcane stalk

Rs 150/ton

Recovery of sugar decline as delay in harvesting

Yes due to smoke there is health risk

Yes many studies reported for rise in temperature and air pollution
The profit margin per hectare obtained from sugarcane planted and ratoon crop for burning practices was 2.51 and 2.70 . The table also explains that the overall per quintal cost of production of sugarcane planted and ratoon crop was Rs. 161.03 and Rs. 144.51 per quintal. Per hectare percent loss in return over non straw burning practices for sugarcane planted and ratoon was 11.61 and 13.71 percent, respectively. 


\section{Reasons of straw burning practices in sugarcane}

The sugarcane plant consists of about 75 percent to 80 percent net cane (stalks) from which the juice is extracted and the sugar crystallized. The other 20 percent to 25 percent of the plant consists of leafy material, including tops, from which little or no sugar is produced. This leafy material is called trash. Burning sugarcane before harvest removes from one-half to two-thirds of this trash that would otherwise contribute nothing to sugar production.

Farmers' burn sugarcane to reduce the amount of leafy extraneous material, including stalk tops, delivered with the cane to the factories for processing. A prescribed burn is used in sugarcane production to reduce the trash in harvested cane. This prescribed burn can occur in standing cane. Traditionally farmers of South Gujarat region burn their sugarcane before harvesting of the crop.

Sugarcane field burning is carried out before harvesting of the crop to make the process easier and require less labour and also reduce transportation cost. Sugar factory also benefited by reducing weight and recovery of sugar. Yield weight loss is up to 10-12 tonnes /ha. In burning process, the field is set fire to and the leaves are burned off of the stalks. About $80 \%$ of the trash including straw, the tops and green and dry leaves are burned off. These components constitute about $25 \%$ of the entire sugarcane stalk. The sugar factory deducts Rs. 150/tones if farmers burn their sugarcane. Another side effect of burning is environmental pollution by ash and rise in temperature (Table 4).

The per hectare cost of cultivation of nonstraw burning practices for sugarcane planted and ratoon was Rs. 184990 and Rs.132779.
The total cost of cultivation for sugarcane straw burning practices was Rs. 175365 and Rs.124621for sugarcane planted and ratoon crop, respectively. The net return per hectare for sugarcane burning practices of sugarcane planted and ratoon crop was Rs. 225387 and Rs.181687. Traditionally sugarcane farmers burn their crop before harvesting of the crop to reduce labour and transportation cost. The burning practices of the farmers reduce their income by deduction of Rs. 150 per tonnes and weight loss of 10-12 tonnes per hectare.

\section{References}

Aquino, GS, Medina, CC, Costaa, D.C., Shahab, M., Santiago, A. D. 2017. Sugarcane straw management and its impact on production and development of rations. Industrial Crops and Products, 102: 58-64.

Aquino, GS, Medina, CC, Tronchini, ER, Pasini, A., Menezes Junior, AO, Hoshino, AT, Oliveira, EC, Brito, OR. 2016. Root system and yield of sugarcane cultivated under different amounts of straw in southern Brazil. Afr. J. Agric. Res. 11(7): -571.

Ball-Coelho, B., Tiessen, H., Stewart, J.W.B., Salcedo, I.H., Sampaio, E.V.S.B. 1993. Residue management effects on sugarcane yield and soil properties in northeastern Brazil. Agronomy Journal, 85: 1004-1008.

Braunbeck, O.A. and Magalhães, P.S.G. 2010. Technological evaluation of mechanization of sugarcane, in: Cortez, L.A.B. (Coord.). Bioethanol from sugarcane: $\mathrm{R} \& \mathrm{D}$ to productivity and sustainability, São Paulo P 556.

Cardoso, T.F., Cavalett, O., Chagas, M.F., Morais, E.R., Carvalho, J.L.N., Franco, H.C.J.,Galdos, M.V., Scarpare, F.V., Braunbeck, O.A., Cortez, L.A.B., Bonomi, A. 2013. Technical and economic assessment of trash recovery 
in the sugarcane bioenergy production system. Sci. Agric, 70 (5):353-360.

Costa, L.G., Marin, F.R., Nassif, D.S., Pinto, H.M., Lopes-Assad, M.L.R.C. 2014. Simulating trash and nitrogen management effects on sugar cane yield. Rev. Bras. Eng. Agríc. Ambient, 18(5): 469-474

França, D. A., Longo, K. M., Neto, T.G. S., Santos, J. C., Freitas, S.R., Rudorff, B.F. T., Cortez, E.V., Anselmo, E. and Carvalho Jr, J.A.2012. Pre-Harvest Sugarcane Burning: Determination of Emission Factors through Laboratory Measurements. Atmosphere, 3:164-180.

Jain, N., Bhatia, A., Pathak H. 2014. Emission of Air Pollutants from Crop Residue Burning in India. Aerosol and Air Quality Research, 14: 422-430.

Kant, K., Siddharth P. T. and Mamta Meena (2015). Cost of cultivation of sugarcane crop in Meerut district of Uttar Pradesh International Journal of Forestry and Crop Improvement, 6 (1): 41-48 retrieve from $w w w . r e s e a r c h j o u r n a l . c o . i n$

Koppmann, R., Czapiewski, K.V. and Reid, J.S. 2005. A Review of Biomass Burning Emissions Part I: Gaseous Emissions of Carbon Monoxide, Methane, Volatile Organic Compounds, and Nitrogen Containing Compounds. Atmos. Chem. Phys. Discuss. 5: 10455 10516 .
Kumar, T., Singh, H.L., Jawala, S.K. and Sachin, S. 2014. Cost and return of sugarcane production at different size groups of farms in district Meerut (U.P.), India. Annals of Agri-Bio Research, 19(5): 561-565.

Oliveira, M.W., Trivelin, P.C.O., Kingston, G., Barbosa, M.H.P., Vitti, A.C.2002. Decomposition and release of nutrients from sugarcane trash in two agricultural environments in Brazil. Proceedings of the Conference of Australian Society of Sugar Cane Technologists, 24: 1-10.

Singh, S.P., Gangwar, B. and Singh, M.P. 2008 Economics of Sugarcane-based Farming System in Western Uttar Pradesh Agricultural Economics Research Review, 21(1): 109-117

Streets, D.G., Yarber, K.F., Woo, J.H. and Carmichael, G.R. 2003. An Inventory of Gaseous and Primary Aerosol Emissions in Asia in the Year 2000. J. Geophys. Res. 108: 8809-8823, doi: 10.1029/2002JD003093.

UNICA 2015. Which the planned expansion for the cultivation of sugarcane in Brazil in the coming years? Retrieve from: http://www.unica.com.br/FAQ/.

Yang, S., He, H., Lu, S., Chen, D. and Zhu, J.2008. Quantification of Crop Residue Burning in the Field and its Influence on Ambient Air Quality in Suqian, China. Atmos. Environ. 42: 1961-1969.

\section{How to cite this article:}

Narendra Singh, V.M. Thumar, A.K. Leua and Chaudhari, D.J. 2018. Impact of Straw Burning Practices on Economics of Sugarcane in South Gujarat Region, India. Int.J.Curr.Microbiol.App.Sci. 7(09): 234-241. doi: https://doi.org/10.20546/ijcmas.2018.709.030 